\title{
Decision tools for managing insect pest outbreaks in pastures
}

\author{
S.M. ZYDENBOS ${ }^{1}$, C.M. FERGUSON ${ }^{2}$, R.J. TOWNSEND ${ }^{1}$, J.E. DUNBAR ${ }^{3,4}$, S. PEOPLES ${ }^{2}$, \\ B.E. WILLOUGHBY ${ }^{5}$, P.M.S. LANE ${ }^{6}$ and T.A. JACKSON ${ }^{1}$ \\ ${ }^{1}$ AgResearch Lincoln, Private Bag 4749, Christchurch 8140, New Zealand \\ ${ }^{2}$ AgResearch Invermay, Private Bag 50034, Mosgiel 9053, New Zealand \\ ${ }^{3}$ Landcorp Cape Foulwind, 332 Wilson's Lead Road, RD 2, Westport 7892, New Zealand \\ ${ }^{4}$ Bio-Protection Research Centre, Lincoln University, PO Box 84, Canterbury7647, New Zealand \\ ${ }^{5}$ Ecometric Consulting Ltd, 8 Bond St., Hamilton 3216, Waikato, New Zealand \\ ${ }^{6}$ Ballance Agri-Nutrients, Tauranga, New Zealand \\ sue.zydenbos@agresearch.co.nz
}

\begin{abstract}
Outbreaks of insect pests can cause major losses in pasture productivity, but farmers are often poorly equipped to evaluate risk factors, predict pest impacts and determine appropriate control actions. Decision tools are described for pasture pest management using three case studies. For grass grub, "at risk" paddocks are identified based on factors such as time since sowing, soil type and larval damage the previous autumn/ winter. Targeted populations measurements can then be taken and a decision to control grass grub made using this objective measurement and/or an assessment of the pasture value, termed the insurance approach. For manuka beetle, pesticide application decisions are based on damage scores of individual paddocks and the correlation between these scores and larval densities. With porina, information on moth flight times, larval populations and pasture damage are used to make key control decisions. For all pests, decisions to control should be made in conjunction with other farm systems information, including the costs of lost forage production and long-term impacts on pasture persistence.
\end{abstract}

Keywords: grass grub (Costelytra zealandica), porina (Wiseana spp.), manuka beetle (Pyronota spp.), farmer decision-making

\section{Introduction}

Insect pests pose a major challenge to productivity and sustainability of pasture systems through reducing both annual productivity and the quality of the pasture sward (Zydenbos et al. 2011). Farmers recognise that insect attack is primarily responsible for loss of sown species (Tozer et al.2011), but taking action to prevent or manage these pests can be difficult. Insect challenges to pastures are a dynamically complex issue (Miller \& Newell 2013), influenced by climatic, pasture management and intrinsic biological factors. It not surprising, then, that decisions on whether or not to control insect pests in pastoral systems are often not made in a timely manner or are avoided completely. In many situations, this is because the relevant information is not available in readily-accessible formats or appropriate for farmer decision making. Farmers need clear criteria on which to base their pest management decisions that are linked to standard pasture management practices within the whole farm system. For the three cases in this paper, grass grub, manuka beetle and porina, historical information was reviewed and combined with new knowledge to create tools and guidelines for decisionmaking around pasture pest management.

\section{Farmer decision-making for insect pest management}

Key to the management and assessment of insect pests is an awareness of a potential attack on pastures well before any damage is apparent. "Awareness" is made up of many factors, including farmer experience, pest visibility and pest predictability. Farmer empirical knowledge is gained via practical experiences, either directly with pests or through engagement with other farmers who convey their experiential understandings. Direct experiences often influence farmer attitudes towards pest management and therefore become motivationally important within the decision-making process (Coughenour 1980), particularly if there have been significant economic consequences of previous pest damage.

Visual impacts make farmers more aware of some insect pests than others, although what can be seen and therefore acted upon is affected by pest life-stage, time of the year, environmental factors and the size of the pest population present. For example, apart from an annoying aerial assault from beetles flying in November, pastoral farmers will not generally consider grass grub until autumn and winter, when pasture growth rates are at a minimum and grazing pressure means that grass plants devoid of roots are "pulled" from the ground by stock. It is only then that there is awareness of the large patches of pasture with reduced productivity and possibly irreversible damage - and at this stage it may 
be too late to act.

Predictability is an issue with many pasture pests, but through improved depth and breadth of scientific knowledge, uncertainty levels surrounding pest management can be reduced and the unpredictable becomes closer to being predictable. For example, for some significant insect pests of pasture there are many variables that affect whether or not they will cause damage, and so damage outbreaks can be forecast with some degree of confidence. These variables include climate, soil type, paddock history and current status (e.g., pasture species, pasture cover at critical times of the pests' life cycle, time since sowing), pasture inputs and management (e.g., fertiliser, irrigation), grazing animals (the class of stock, grazing frequency and intensity, and stocking rate), and the presence of insect pathogens and predators that may exert natural biological control on insect populations (Jackson et al. 2012; Zydenbos et al. 2011). Some of these variables will be considered in more detail in the case studies presented below.

Scientific knowledge must be conveyed in "farmer friendly" formats. With improved awareness and experience, as well as usable tools to increase predictability, farmers can make informed decisions about the likely severity of pest damage, its economic impact and therefore the value proposition of implementing management and/or control measures. To facilitate this, strategies/tools need to be clearly worded and easily implemented so they form part of a "decision support toolbox" that farmers and associated industry field representatives can utilise with confidence.

A critical aspect of managing insect pests is accurate identification. For example, while they differ in form and feeding habit, people still confuse grass grub and porina. Many farmers are unaware that several insects, e.g., manuka beetle, Odontria species, redheaded cockchafer and Tasmanian grass grub, which are minor pests in their own right, closely resemble grass grub in the larval stages. In the North Island, in particular, insect pest complexes may affect pastures simultaneously, e.g., black beetle (Heteronychus arator), grass grub and Tasmanian grass grub (Aphodius tasmaniae); introduce porina into this mix, and the need for accurate identification of the pest in order to make use of decision support tools becomes readily apparent.

Differences between insect pest species are expressed in the type and timing of damage, mitigation strategies required and crucially predictability. While there are excellent background scientific papers available through the freely-available and easilysearchable NZPPS and NZGA websites, specific printed references for New Zealand pasture pests that are readily accessible and understandable by farmers and industry representatives (e.g., Barratt et al. 1990; Ferro 1978; Helson 1974) are largely outdated. A recent innovation has been the online identification website PestWeb ${ }^{\mathrm{TM}}$ (www.pestweb.co.nz; Tozer et al. 2009). Developed specifically for the pastoral industry, PestWeb ${ }^{\mathrm{TM}}$ includes a simple system for identifying the pests (and weeds) present and provides guidelines for management of these pests. In addition, participants can sign-up for the free "alert" service, where timely email or text reminders are sent out to advise farmers when they should be checking for a specific pest or if there is an outbreak. The site is regularly being updated with new pests and information, and new strategies to improve ease of use are being developed (such as making the site mobile- and tablet-friendly) (Katherine Tozer, AgResearch, pers. comm.).

Specific tools for each of three insect pests, grass grub, manuka beetle and porina, are discussed below.

\section{Grass grub}

The larval stages of the native New Zealand grass grub (Costelytra zealandica) damage pasture plants by feeding on their roots. Jackson et al. (2012) highlighted the risks from catastrophic grass grub damage associated with large-scale improvement of pastures, such as during irrigation development or conversion from forestry. More commonly, damage is caused as a result of outbreaks initiated by cultivation and very dry summers. Much data on grass grub effects in pasture were collected during the 1970s and 1980s, leading to the understanding that grass grub populations steadily increase after sowing, with larval numbers reaching damaging levels 2-4 years into the life of the new pasture (East \& Kain 1982; East et al. 1979).

In 2008 these data were re-validated on renovated pastures in the Waikato region, from Matamata to Taupo. In total, 81 paddocks from 27 properties were assessed after identification by Ballance Agri-Nutrients staff as fitting into the following criteria: (1) 1,2 , or 3 years after re-sowing into permanent pasture, (2) established through cultivation after a maize or turnip crop, and (3) on light, ash-based, free-draining soil with a history of grass grub damage. In addition to this information, other details, such as soil type, climatic conditions since cultivation (e.g. drought) and pasture varieties, were recorded for each paddock. During the period 11 March to 1 May 2008, grass grub populations were estimated by taking 100 soil samples $(100 \mathrm{~mm}$ diameter $\times 150 \mathrm{~mm}$ deep) per paddock and handsorting in the field. Larvae were predominantly second or early third larval instars.

Grass grub population size increased steadily with time after sowing (Table 1), with significant differences between each of the three years $(\mathrm{P}<0.01)$. In year 1 , 
populations exceeded $40 / \mathrm{m}^{2}$ in only $4 \%$ of the pastures, but by year 3 this value was $67 \%$ (Table 1 ). No pastures in years 1 or 2 had grass grub populations over $250 / \mathrm{m}^{2}$, but $4 \%$ of year 3 pastures reached this level. Pasture age is therefore very important for identifying paddocks "at risk" from grass grub attack.

Other tools can be used in the decision-making process. For example, understanding the insect life cycle allows checks to be made at critical times of the year. With grass grub, the first of these should be a "winter check". This should start with a 1-year-old pasture, but particular attention needs to be paid to second and third year pastures. Any pulling, yellowing patches or bare areas, and the extent of these, should be recorded. Severe damage patches should be inspected and any larvae positively identified as grass grub. This is an important step as the symptoms may be caused by other factors, such as soil conditions. If major damage is occurring immediate treatment must be considered, but if damage is minor the paddock can be noted for early inspection the following year.

In mid to late spring there will be an abrupt reminder of the presence of grass grub in pastures when adult beetles begin flying around dusk. At this time, male grass grub beetles can be detected using pheromone traps (Townsend et al. 2013; Unelius et al. 2008), which raises awareness of the problem, but the numbers caught do not correlate closely with subsequent larval populations in any individual paddock (R.J. Townsend, unpublished data) and so this is not a useful decisionmaking tool.

The second critical time is during February and March, when larval numbers can be estimated 1-2 months before damage becomes apparent, and based on that information, active intervention to control grass grub can be planned. This should be done by digging 10 or more spade squares to a depth of $10-15 \mathrm{~cm}$ from throughout the paddock, and hand-sifting through the soil to collect the larvae. If a 20 -cm (8-inch)-width spade is used, then four larvae per spade square is approximately $100 / \mathrm{m}^{2}$ (if a 15 -cm (6-inch)-width spade is used, $100 / \mathrm{m}^{2}$ is represented by about 2 larvae per spade square). Sampling is usually only needed in young pastures that have been determined as being "at risk" based on previous history. However, in very dry summers, older pastures are also at risk, either during the drought when the lack of moisture combined with potential overgrazing can reduce the grass grub population damage threshold or 2 years later when damage can be anticipated due to a loss of pathogens during the drought that naturally suppress grass grub populations.

The above information has been compiled into a decision support tool designed to help farmers determine if intervention to reduce grass grub populations or another mitigation strategy (e.g., nitrogen application, sourcing extra supplementary feed) is necessary (Table 2). It is important to note that actual dates will vary throughout New Zealand according to climate. For example, beetle flights will begin earlier in Waikato (October) and later for Southland (NovemberDecember) (Barratt et al. 1990). In addition, thresholds for applying control strategies to reduce grass grub populations will vary with farming systems and regions, and should be adapted to suit individual farms.

The decision support tool outlined in Table 2 facilitates the early identification of "at-risk" pastures and strategic autumn sampling to determine those pastures where control is likely to reduce the chance of economic damage occurring to a pasture. A complementary approach to assisting with the decision of whether or not to apply a treatment to reduce grass grub numbers is an assessment of the pasture's value "the insurance policy" approach. As with all insurance policies it pays to neither over- nor under-insure. Estimating the value of the pasture to the farm and then protecting it if it is perceived to be "at-risk" from grass grub damage is key to this process. While an indication of the grass grub population is helpful, quantification through spade-square sampling is not essential as other factors are used to determine the "pasture score". This approach is summarised in Table 3. It must be noted that it is very important to first confirm that a grass grub infestation is likely, using the first eight criteria outlined in Table 2.

\section{Manuka beetle}

Manuka beetles (Pyronota spp.) are native insects of which there are several species. The larvae are smaller than grass grub but cause similar damage by feeding on pasture plant roots causing decreased pasture growth and plant death. Traditionally manuka beetle has been only considered a pest in areas close to manuka bush (Thomson et al. 1978), but recently large-scale pasture development at Cape Foulwind on the West Coast of

Table 1 Grass grub populations (numbers $/ \mathrm{m}^{2}$ ) sampled in autumn 2008 from 81 pastures that were 1,2 or 3 years post-cultivation in the Waikato region.

\begin{tabular}{lccc}
\hline & Year 1 & Year 2 & Year 3 \\
\hline Grass grub population mean (range) & $10(0-99)$ & $51(1-153)$ & $84(2-379)$ \\
Proportion of populations $>40 / \mathrm{m}^{2}$ & $4 \%$ & $52 \%$ & $67 \%$ \\
Proportion of populations $>75 / \mathrm{m}^{2}$ & $4 \%$ & $22 \%$ & $52 \%$ \\
\hline
\end{tabular}


the South Island induced a major outbreak (Jackson et al. 2012; Townsend et al. 2010).

Initially farmers misidentified manuka beetle larvae as grass grub, although the latter had not been detected in the region until recently (Townsend et al. 2013). With initial investment by Landcorp and subsequent support from the Ministry of Primary Industries' Sustainable Farming Fund, researchers and farmers worked together to correctly identify the insects responsible for the major pasture damage being observed in the region, determine the lifecyles of the pest species, define adult beetle flight patterns (R.J. Townsend \& J.E. Dunbar, unpublished data), and investigate potential methods for manuka beetle control (Townsend et al. 2010).

As part of this project, pasture damage was related to manuka beetle larval density. Assessments took place in recently established pastures on flipped land on Bassett's Block (470 ha), Landcorp Farming Ltd,

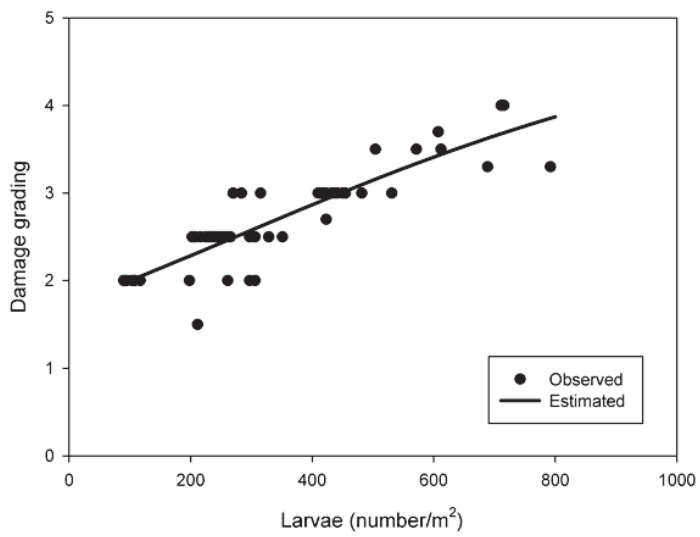

Figure 1 Damage by manuka beetle expressed as a visual grading in relation to larval population in the soil (number $\left./ \mathrm{m}^{2}\right)$. The fitted line shown is a logistic curve with the equation: Damage $=5 /(1+\exp (($ 273.51 - Larval number ) / 427.5 )).

Table 2 A decision support tool for determining whether a biological or chemical control for grass grub should be applied to a specific paddock.

\begin{tabular}{|c|c|c|}
\hline Paddock name and date: & Answer & Definitely consider treatment if all answers are: \\
\hline Is this a grass grub prone area? & & Yes \\
\hline Is this a light or heavy soil? & & Medium to light (free-draining) \\
\hline How old is the pasture? & & $2-4$ years from sowing \\
\hline Was it cultivated or direct-drilled? & & Cultivated \\
\hline Are the pasture species susceptible to grass grub? & & Ryegrass and white clover \\
\hline Was it damaged the previous April-July? & & Yes \\
\hline Were beetles seen on the farm in spring? & & Yes \\
\hline Are the larvae grass grub? & & Yes \\
\hline \multirow{2}{*}{$\begin{array}{l}\text { How many grass grub larvae in mid-Feb to mid-March? } \\
\text { Establish by sampling } 10 \text { or more } 20-\mathrm{cm} \text { spade squares } \\
\text { per paddock, and calculating the average. } \\
\text { Note: } 4 \text { larvae per spade square }=100 / \mathrm{m}^{2} \text {. }\end{array}$} & & $\begin{array}{l}\text { 4-12 grubs per spade square } \\
\text { ACTION: consider biological control treatment }\end{array}$ \\
\hline & & $\begin{array}{l}12 \text { or more grubs per spade square } \\
\text { ACTION: consider insecticide treatment, followed by } \\
\text { biological control treatment next year }\end{array}$ \\
\hline
\end{tabular}

Table 3 Criteria for establishing the value of a pasture in relation to making a decision around the need to control grass grub to protect the pasture or to renovate the pasture to restore its value.

\begin{tabular}{|c|c|}
\hline Pasture value score & Score criteria \\
\hline 5 & $\begin{array}{l}\text { Composition predominantly retaining sown species; high genetic merit cultivars. Less than } 3 \text { years } \\
\text { since sowing. High value pasture with perceived risk from grass grub. } \\
\text { ACTION: Clear candidate for treatment to reduce grass grub population. }\end{array}$ \\
\hline 4 & $\begin{array}{l}\text { Composition retaining a minimum of } 80 \% \text { of sown species; high genetic merit cultivars. Less than } 3 \\
\text { years since sowing. High value pasture with perceived risk from grass grub. } \\
\text { ACTION: Candidate for treatment to reduce grass grub population. Consider "stitching-in" grass seed } \\
\text { with treatment. }\end{array}$ \\
\hline 3 & $\begin{array}{l}\text { Composition retaining around } 60 \% \text { of sown species, but cover possibly patchy and/or not likely to } \\
\text { have high genetic merit cultivars. } \\
\text { ACTION: Close evaluation needed of potential return on investment in grass grub control and/or un- } \\
\text { der-sowing with new pasture species. }\end{array}$ \\
\hline 2 & $\begin{array}{l}\text { Composition retaining less than } 50 \% \text { of sown species. } \\
\text { ACTION: Will most likely require complete renewal. }\end{array}$ \\
\hline 1 & $\begin{array}{l}\text { Low value pasture. } \\
\text { ACTION: Requires complete renewal. }\end{array}$ \\
\hline
\end{tabular}


Table 4 Visual damage scale used to estimate manuka beetle larval damage in West Coast dairy pastures.

\begin{tabular}{cll}
\hline Damage score & Description & Representative image \\
\hline 1 & No visible damage &
\end{tabular}

2 Some small patches of weak growth and lifting of plants with patches covering $<20 \%$ of the defined area.

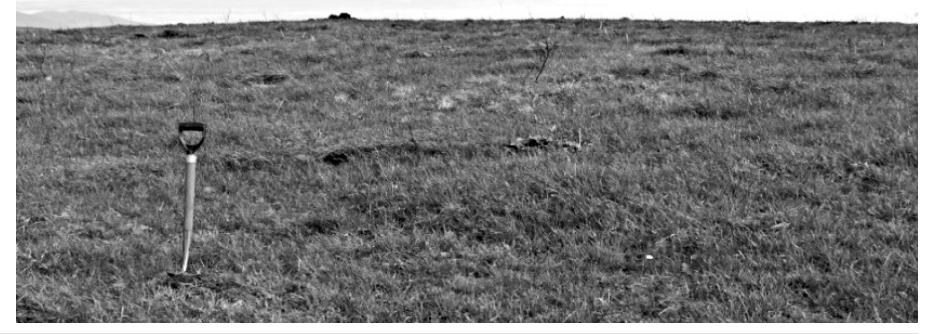

3 Patches of damage evident covering 20-40\% of the area. Pulling of plants obvious after grazing with dead plants on the surface

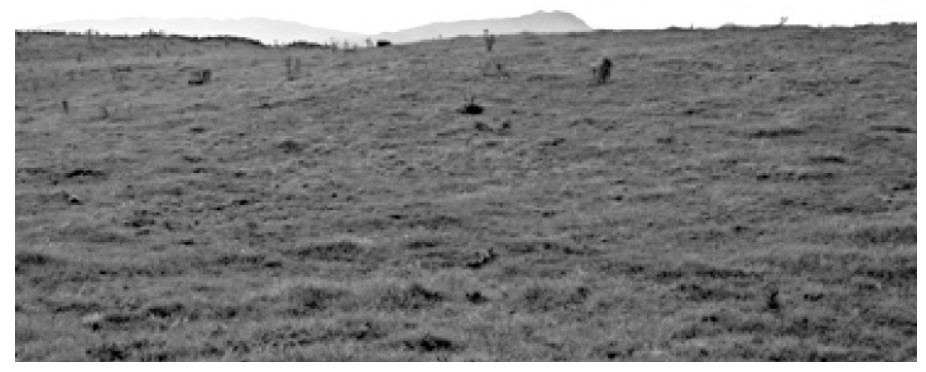

$4 \quad$ Damage patches and pulling after grazing widespread (40-60\%). Poor pasture performance with little growth in autumn. Weed ingress.

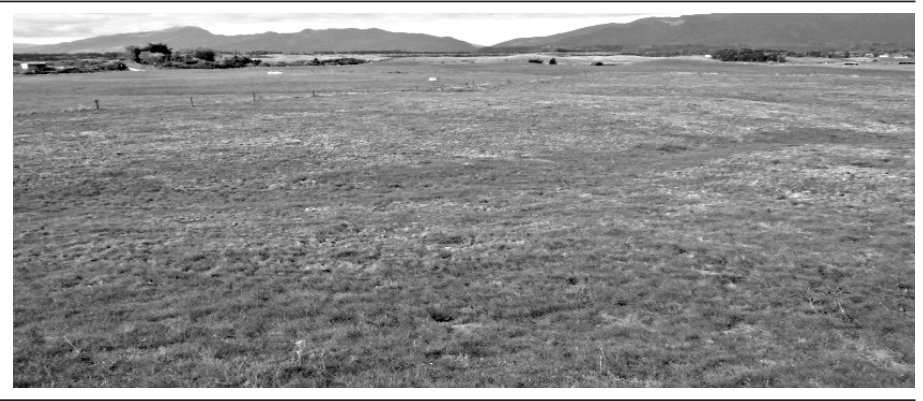

$5 \quad$ Most of pasture damaged with weak, stressed or dead plants. Strong weed growth.

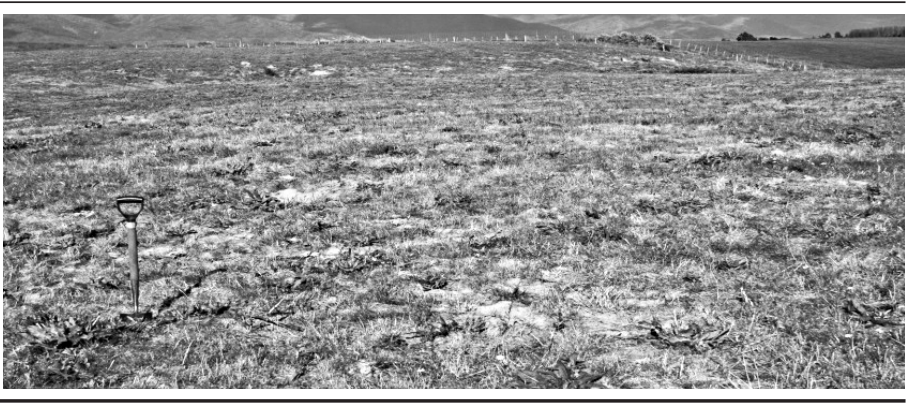


Cape Foulwind. Pastures were mostly ryegrass/clover and had been sown in the previous 10 years during development of the property. Average paddock size was 4.5 ha. The soil types typically consisted of light grey sand or yellow, coarse beach sand and clays.

Paddock damage scores were developed by consensus based on visual estimation of the proportion of the paddock showing damage on a 1-5 scale (Table 4). If different levels of damage were noted in different parts of the paddock, the paddock was divided into four equal sections, which were then scored, and a paddock mean established by averaging the four estimates. Paddocks were graded by two observers after walks across the pasture in April 2009. In total, 59 paddocks were scored in this manner. Larval populations were estimated by digging 10 spade samples $(15 \times 15 \times 15 \mathrm{~cm})$ per paddock and hand-sorting the soil to detect larvae.

Most (48/59) pastures showed some sign of damage and were graded $>2$, while two pastures were graded with a score of 4 . Manuka beetle populations on the monitored paddocks averaged 345 third instar larvae/ $\mathrm{m}^{2}$ (range 90-792). Paddock damage scores were compared with manuka beetle larval density and the observations are plotted in Figure 1. Three models were fitted to the data using the statistical software $\mathrm{R}$ version 2.8.1: linear and quadratic models using the $l m$ function and a logistic curve model using the $\mathrm{nlm}$ function. The Akaike Information Criterion (AIC) is a common criterion used for selecting the most appropriate statistical model. AIC values were 10.56, 11.65 and 9.34 for the linear quadratic and logistic models respectively, indicating that the logistic model, shown in Figure 1, was the most appropriate fit for these data. This analysis clearly demonstrates that the damage score assessment can be used to estimate manuka beetle larval populations in pastures that are affected by the pest. For example, pastures with a mean damage score of 2.6 would be expected to have a manuka beetle population of around 300 larvae $/ \mathrm{m}^{2}$.

Farmers have few options available to reduce manuka beetle populations in pasture and have had to rely on the broad spectrum insecticide, diazinon. A threshold of $>300$ larvae $/ \mathrm{m}^{2}$ was established by the manuka beetle management group in 2010 above which it was beneficial to apply insecticide in autumn. Because the scale of infestation was very large, it was impracticable to dig and count larvae in all at-risk pastures. The damage score/larval density relationship in Figure 1 provided a practical alternative. Using this, pastures with a damage score of 3 were identified as candidates for insecticide treatment, while those with a score above 4 were prioritised for renewal. As for all agricultural pests, the decision to control manuka beetle larvae must take into account farm systems information, such as the cost of alternative forage and expected returns for the milk, meat or wool produced.

\section{Porina}

Porina is a complex of endemic moth species, Wiseana spp. whose larvae significantly affect pasture production and plant composition in many parts of New Zealand. Porina life history and larval development are well understood and the onset of damage can be related to larval development stage, which will vary depending on the timing of moth flights. For early flying species, pasture damage is generally first noticed by farmers in late autumn and becomes more severe through winter as larval body sizes increase and plant growth slows, by which time pasture production losses have occurred and may be irreversible because of plant death. For later flying species damage may not be noticed until midlate winter.

Investigations into naturally occurring diseases of these pests (e.g., Crawford \& Kalmakoff 1977; Fleming et al. 1986) have allowed an understanding of natural population dynamics, enabling the prediction of potentially damaging populations. When associations between obligate pathogens and the insects are disrupted, the insect populations are subsequently able to increase to damaging levels. The most common causes of disruption are abnormally dry weather in late spring and summer, and cultivation for pasture renewal. High porina densities will result 2-4 years after the disruption.

Measurements of porina densities before damage starts to occur can be used to predict the severity and cost of the potential damage (Garnham \& Barlow 1993). In the case of cultivation, damage is likely to occur only to paddocks that have recently been renovated and this regularly occurs in porina prone areas. However, in the case of dry summers, damage can occur at farm and district scales, with pastures of all ages affected, as

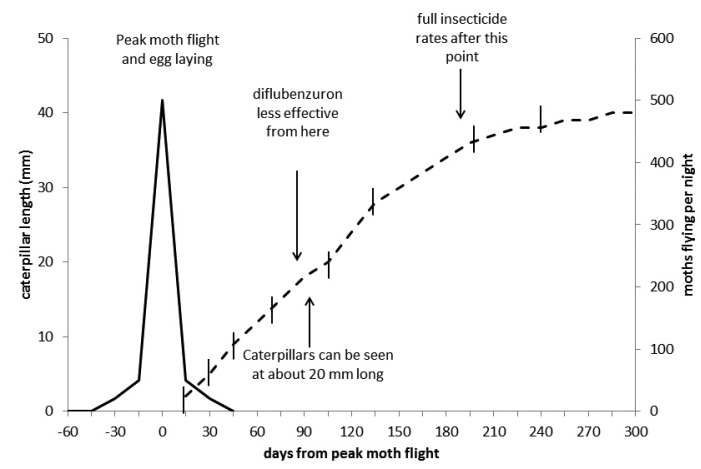

Figure 2 Peak porina moth flights (solid line), approximate caterpillar size $(\mathrm{mm})$ (dashed line) and time of larval moults (small vertical lines). Adapted from Ferguson \& Crook (2004). 
happened in the lower North Island in 2011 and 2012. It is possible therefore to estimate the risk of damage outbreaks based on climate and pasture history 2-4 years before it occurs (although the precision of this can be \pm 1 year).

When there is a risk of high porina populations developing, farmers can implement a decision-making process, based on porina development and simple population assessment, which allows them to maximise economic returns by intervening against porina before damage occurs. This begins by recording when porina moths are flying, which will be apparent when they bang into lit windows at night or flutter around outside lights. Flights are usually in mid/late spring and again in mid summer, but also occur in late summer/early autumn in the lower North Island. Eggs are laid during these flights, giving rise to caterpillars whose growth is governed by temperature and can be predicted (Ferguson \& Crook 2004). The timing of the moth flights therefore indicates what stage of development the caterpillars will reach at any particular time (Figure 2 ). This is particularly important if the insect growth regulator diflubenzuron is used, as this cheap product is most effective if applied within 12 weeks of the moth flight (Figure 2) when the caterpillars are small and moulting frequently (Ferguson \& Crook 2004). It is important to monitor moth flights because different species may fly at different times, and if there are two flights the caterpillars arising from each may have to be targeted separately. Applying diflubenzuron based on time after moth flights is basically an insurance

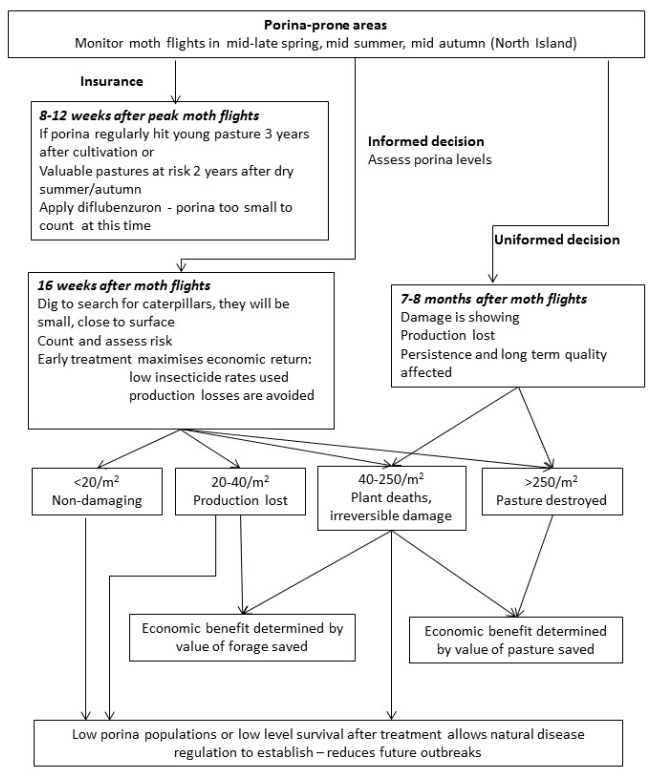

Figure 3
A decision-making flow diagram to manage porina attack. policy, as at this time caterpillars are too small to be easily found.

If the insurance policy approach is not used, at-risk pastures can be inspected 4 months after moth flights, at which time the caterpillars are inhabiting the top 50 $\mathrm{cm}$ of soil. Sampling to do this is straightforward, by digging and carefully hand-sorting the soil from 15 to 20 spade squares/pasture, and teasing apart the turf layer to find and count the still small porina (Figure 2). The density estimates obtained can indicate the severity of the impending impact and enable cost-benefit analyses. Damage begins when porina are present at 20-40/ $\mathrm{m}^{2}$ and increases in severity with increasing density (Figure 3). Should the densities measured at sampling indicate that mitigation would be beneficial, this can be implemented early before damage appears, thereby preventing even minor production losses. At this time lower rates of insecticide can be used than would be required for large larvae, substantially reducing control cost. Diflubenzuron may still be an option if the caterpillars are smaller than 15-20 mm long, but more likely, especially if numbers are high, a conventional insecticide will be the only recourse.

If neither the insurance policy nor informed decision approaches (Figure 3) have been followed, and porina damage is recognised 7 to 8 months after moth flights, the only mitigation option is to apply conventional insecticide at the recommended label rates. This will not redress lost production that has already taken place but may prevent pasture plants being killed.

Figure 3 is a tool that can be used to assist farmers to make decisions about management of porina outbreaks. However, like the tools for assisting with grass grub and manuka beetle management, these are guidelines only and must be adapted for the particular needs of the farm system.

\section{Discussion}

Practical tools that farmers can use to assess the level of grass grub, manuka beetle and porina infestation on their farms have been presented here. These tools include guidelines for decision-making around options for controlling the pests and should be combined with other information relevant to the whole farm system. While based on historical information, these tools have been updated to include new information and have been adapted to emphasise a greater level of flexibility than has been suggested in the past. For example, while digging holes in pastures remains the standard protocol for assessing the resident populations of these damaging soil-dwelling larval stages, alternatives have also been presented. These include the "insurance approach", where a decision to apply an insecticide is based on the time since the pasture was sown (for 
grass grub) or the timing of moth flights (for porina). In addition, a pasture damage score of 3 is the criterion for applying diazinon to control manuka beetle on farms in Cape Foulwind.

Information about the potential need for control of insect pests can be collected throughout the year as part of standard farm management processes, e.g., pasture production assessments. This includes verifying the actual insect species present, whether a complex or singular. This information can then be used to make proactive decisions at pre-defined time points about insect pest management, rather than acting retrospectively when significant and irreversible damage has already occurred.

Ferguson \& Peoples (2013) highlighted the importance of scientists understanding the attitudes and decision-making behaviours of farmers towards insect pest management and their comprehension of current pest information. By knowing how pest-aware farmers are, what they are prepared to do to manage those pests and what they expect from the mitigation solutions, scientists will gain a greater appreciation of farmer behaviour, their potential for change and where to target any information or tools. Whilst many of the steps discussed above appear "simple" to professional "pest management experts", this is not necessarily the case for farmers whose knowledge and expertise must cover a very broad range of bio-physical, economic and social topics. To expect them to be constantly aware of what pests might be doing is, in most cases, unrealistic.

The PestAlert function of PestWeb ${ }^{\mathrm{TM}}$ is designed to prompt farmers at critical times to think about pests and the implications of non-action. However, on its own this is not enough to create a broad awareness. Hence, there is a role for associated industry personnel, with sufficient training and knowledge, to work with farmers and be involved in the pest prediction and management decision-making process.

This paper has focused on decision support tools for identifying and predicting insect damage and implementing appropriate control measures. Farmers must link these damage indicators with financial decisions that are integrated within their whole farm system, using Farmax and other models that take into account feed supply and demand and expected returns for the milk, meat or wool produced.

\section{ACKNOWLEDGEMENTS}

Chikako van Koten, AgResearch, for statistical analysis of the relationship between pasture damage scores and manuka beetle larval populations; Paul Hateley and the staff at Landcorp Farming Ltd, Cape Foulwind, for assistance with manuka beetle population and pasture assessments; Ballance Agri-Nutrients staff, particularly
Hadleigh Putt and Andrew Rutherford, who tested the grass grub decision support tool; Alison Popay and Scott Hardwick, AgResearch, who both reviewed an earlier version of this manuscript.

We also acknowledge funding and in-kind support from MBIE (LINX0804), SFF (09-080; L12-133), Landcorp Farming Ltd, Ballance Agri-Nutrients and Ministry for Primary Industries Clearview Primary Growth Partnership programme that has enabled this work to be conducted.

\section{REFERENCES}

Barratt, B.I.P.; van Toor, C.F.; Ferguson, C.M.; Stewart, K.M. 1990. Grass grub and porina in Otago and Southland. A guide to management and control. Ministry of Agriculture and Fisheries, Mosgiel, New Zealand. 104 pp.

Coughenour, C.M. 1980. Farmers, location, and the differentiation of crops from livestock farming. Rural Sociology 45: 569-590.

Crawford, A.M.; Kalmakoff, J. 1977. A host-virus interaction in a pasture habitat: Wiseana spp. (Lepidoptera: Hepialidae) and its baculoviruses. Journal of Invertebrate Pathology 29: 81-87.

East, R.; Kain, W.M. 1982. Prediction of grass grub, Costelytra zealandica (Coleoptera: Scarabaeidae) populations. New Zealand Entomologist 7: 222-226.

East, R.; Kain, W.M.; Douglas, J.A. 1979. The effect of grass grub on the herbage production of different pasture species in the pumice country. Proceedings of the New Zealand Grassland Association 41: 105-115.

Ferguson, C.M.; Crook, K.E. 2004. The development of two Wiseana species and the implications for their management as pastoral pests. pp. 87-93. In: Proceedings of the 8th Australasian Grasslands Invertebrate Ecology Conference.

Ferguson, C.M.; Peoples, S. 2013. Pasture pests are they the real problem? p. In press. In: XXII International Grassland Congress.

Ferro, D.N. 1978. New Zealand insect pests. Lincoln University College of Agriculture, Lincoln, New Zealand. $311 \mathrm{pp}$.

Fleming, S.B.; Kalmakoff, J.; Archibald, R.D.; Stewart, K.M. 1986. Density dependent virus mortality in populations of Wiseana (Lepidoptera: Hepialidae). Journal of Invertebrate Pathology 48: 193-198.

Garnham, M.L.; Barlow, N.D. 1993. Defining the cost of grass grub. pp. 32-38. In: Proceedings of the 6th Australasian Grasslands Invertebrate Ecology Conference.

Helson, G.A. 1974. Insect Pests. Ministry of Agriculture and Fisheries New Zealand Bulletin 413, Wellington, New Zealand. 196 pp. 
Jackson, T.A.; Townsend, R.J.; Dunbar, J.E.; Ferguson, C.M.; Marshall, S.D.G.; Zydenbos, S.M. 2012. Anticipating the unexpected - managing pasture pest outbreaks after large-scale land conversion. Proceedings of the New Zealand Grassland Association 74: 153-158.

Miller, C.; Newell, B. 2013. Framing integrated research to address a dynamically complex issue: The red headed cockchafer challenge. Agricultural Systems 117: 13-18.

Thomson, N.A.; Rys, G.; Carpenter, A. 1978. Control of manuka beetle. Proceedings of the 31 st New Zealand Weed and Pest Control Conference: 164-166.

Townsend, R.J.; Dunbar, J.E.; Jackson, T.A. 2013. Grass grub distribution on the upper West Coast defined by soil sampling and pheromone trapping. New Zealand Plant Protection 66: 376 (abstract only).

Townsend, R.J.; Nelson, T.L.; Jackson, T.A. 2010. Beauveria brongniartii - a potential biocontrol agent for use against manuka beetle larvae damaging dairy pastures on Cape Foulwind. New Zealand Plant Protection 63: 224-228.
Tozer, K.N.; Cameron, C.A.; Thom, E.R. 2011. Pasture persistence: farmer observations and field measurements. Pasture Persistence Symposium. Grasslands Research and Practice Series 15: 25-30.

Tozer, K.N.; Ferguson, C.M.; Glennie, S. 2009. Pestweb: a weed and pest information source for farmers. New Zealand Plant Protection 62: 415 (abstract only).

Unelius, C.R.; Townsend, R.J.; Mundy, D.C.; Manning, L.M.; Jackson, T.A.; Suckling, D.M. 2008. Comparison of traps and lures for monitoring of grass grub, Costelytra zealandica. New Zealand Plant Protection 61: 215-221.

Zydenbos, S.M.; Barratt, B.I.P.; Bell, N.L.; Ferguson, C.M.; Gerard, P.J.; McNeill, M.R.; Phillips, C.B.; Townsend, R.J.; Jackson, T.A. 2011. The impact of invertebrate pests on pasture persistence and their interrelationship with biotic and abiotic factors. Pasture Persistence Symposium, Grassland Research and Practice Series 15: 109-117. 
